\title{
A systemic perspective on sustainable governance of protected areas
}

\author{
Frieder Voll \& Tobias Luthe
}

Keywords: protected area categories, visitors, partnerships, literature review, international context

\section{Abstract}

This paper discusses systemic aspects of protected area research with a particular focus on systemic governance. Protected areas are embedded within a dynamic system of socioeconomic-ecological interactions on various geographical, value-ethical, cultural and political scales. For example, recent energy politics exacerbates existing pressures on land use for renewable energy generation and challenges the goals and objectives of protection categories. The category or classification of a protected area according to the IUCN framework is influenced by the regional political and cultural differentiations, which concern all aspects of protected areas in their social, ecological and economic interactions. The category has an influence on how the local population is affected or benefits from the protection of an area, and what kind of visitors are coming to or engaging with the protected area. The category is also influenced by the acceptance of the local population and visitors or tourists. Protected areas increasingly operate as multifunctionally managed areas where visitors and inhabitants are integrated into the management concept. Category groups have a decisive and inverse influence on visitor management and protected area governance, which itself is steered by political and cultural characteristics. Changing value ethics of visitors affect the governance of protected areas and new partnerships need to be built for their sustainable management. This paper synthesizes such systemic aspects in a mountain context and concludes with an outline for future research.

\section{Protected areas in a systemic context}

Protected areas have evolved from sanctuaries of pure conservation in the early days of their first establishments, with the Yellowstone National Park in North America or the Swiss National Park (SNP) in the European Alps, into today's complex socioeconomic-ecological systems (Scholz 2011), embedded within various interactions and conditions at international, national, regional and local geographical, political, value-ethical and cultural levels (Lockwood 2011; Jentoft et al. 2007). Changing cultural and value-ethical demand by the (local) population and by visitors, expressed more strongly in public discourse and participative processes, climate change, sociographic and demographic change, politically enhanced pressure on land use for renewable energy generation, and overall pressure on land use for population growth and increased leisure time add further layers of complexity to the sustainable management of protected areas. This complex system of protected area management is shown in Figure 1.

Categories of protected areas are central determinants within the interactions between a protected area management and its stakeholders. The category is defined and shaped partly by the interactions of the protected area governance model, including visitor management, by the participation and the support of the local population, and by the consideration of the demand and needs of different visitor segments. The consideration of stakeholder needs (visitors, residents, local businesses and organizations) and the management actions determine whether the protected area can be managed effectively within the mandate of the assigned category. The reverse influences in the triangular relation of the park category on the governing body, on the acceptance and / or participation of the population, on cultural and value-ethical aspects and on natural and social changes, are framed and regulated by public regulations and politics. These interrelations can be understood from different conceptual viewpoints, such as conservation, education or sustainable development, that are interpreted differently in different societies worldwide.

The geographical context of protected areas is another important factor influencing these values as different population densities lead to different premises on which protected area categories are defined, managed and accepted. Mountain regions are areas of highly conflicting aims as these regions are hotspots of biodiversity protection worldwide, providing ecosystem services for human use, such as recreation, tourism and hydro-power energy production, while enabling the preservation of important (natural and cultural) landscapes. The influences of current developments (such as an increase in renewable energy demand) on protected areas worldwide may be detected earlier in sensitive mountain areas, underlining the need for research on protected areas in mountain regions. The systemic relationships described here are illustrated in the following chapters.

\section{Approach within this paper}

This paper discusses systemic interrelations of protected area governance in the relational framework shown in Figure 1 with the current state of research in the literature. Following a general literature review on systemic aspects of protected areas, the paper discusses the potential influences that different cultures, values and related interpretations of concepts may have. The paper compiles actual developments in protected 


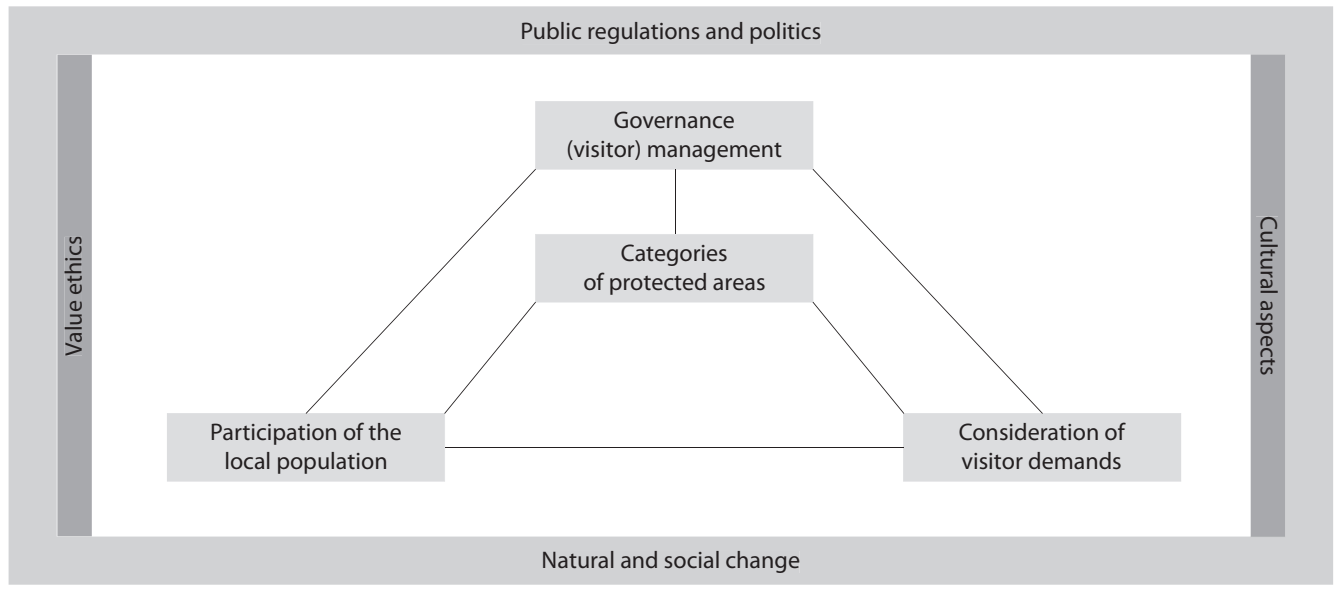

Figure 1 - The relational framework of protected areas as complex socio-economic-ecological systems.

areas worldwide, providing examples from different regions (especially from Europe and North America) with a focus on mountain regions, supporting the argument for comparative discussions of protected area governance in different cultural and political contexts. The paper concludes with a synthesis of such aspects and provides an outlook for future research on systemic aspects of governance in protected areas.

\section{Evolving categories of protected areas}

A new paradigm of protected areas and their management emerged with the World Parks Congress in South Africa in September 2003 (Phillips 2003). "The opening plenary sessions at the Congress featured several speakers who advocated for IUCN protected area categories $V$ (protected landscape) and VI (managed resource areas) as the main focus for protected area activity in the future," (Locke \& Dearden 2005: 1). The definition of new categories, such as category V, Protected Landscape / Seascape, aimed at opening the categories to land, "where the interaction of people and nature over time has produced an area of distinct character with significant aesthetic, ecological and / or cultural value, and often with high biological diversity," (IUCN 1994: 22). While not explicitly stated, the definition incorporates notions of well-being: "contentment, satisfaction, or happiness derived from optimal functioning" (McDowell 2010). Natural ecosystems perform both fundamental life-support services and services that enhance our subjective happiness. The UN Millennium Ecosystem Assessment (2005), for instance, emphasizes the significance of ecosystem services for human well-being and, as a wider research programme, presents case studies for a number of different ecosystems as a way of understanding the complex social-ecological system. The importance of material and non-material ecosystem services for human wellbeing is increasingly being accepted and used as an argument for protecting cultural and natural landscapes.

The two new categories, including cultural landscapes, respond to the fact that in Europe and in developing countries many areas that should be protected are cultural landscapes with high biodiversity but depending on extensive non-industrial land use, which are important for ecosystem services and human wellbeing. As the preservation and protection of ecosystems health, and therefore the ecological integrity, is the main goal in national parks, the idea of strict protection is stronger in societies with a very low population density, such as North America, Oceania and Scandinavia, than for example in Central Europe. It is documented by the number of national parks and designated wilderness areas and the early importance attached to these protection categories in those societies. The designation of wilderness areas plays an important role in the development process of the USA as a nation. In between these geographical contexts with a similar situation we can identify some differences in the public and cultural understanding of wilderness. In Scandinavia, for instance, maintaining a wilderness character includes the protection of the Sami culture and livelihoods and so for instance, the possibilities of hunting in protected areas (Saarinen 2007).

The new categories focus more on sustainable development and consider the conservation of wild biodiversity to a lesser extent (Locke \& Dearden 2005): "The focus of management of category $V$ areas is not conservation per se, but about guiding human processes so that the area and its resources are protected, managed and capable of evolving in a sustainable way," (Phillips 2002: 10). As the management of categories V and VI can, for instance, make sense in distinct areas of Europe and Asia with important intact cultural landscapes, it poses some problems for areas with a higher percentage of wilderness areas: Locke \& Dearden (2005) criticize this new paradigm as recasting protected areas as tools for social planning and income generation instead of strict conservation. These new categories are a problem, especially for protected areas in North America and Scandinavia; for example, the USA named all its national forests, including areas that were heavily logged and used for mining and oil and gas extraction, as category VI areas. As a result the US has almost $40 \%$ of its forest area classified as protected, which does not reflect reality (Bishop et al. 2004; Locke \& Dearden 2005). On the other hand, many of the sites worldwide desig- 
nated to meet the Convention on Biological Diversity Aichi Target 11 will be located within IUCN categories V (Protected Landscapes / Seascapes) and VI (Managed Resource Protected Area) (McCool et al. 2012).

Current discussions about the sustainable production of energy in protected areas in Europe (e.g. at the Rheinfall or in the Naturpärke in Europe) show that there are diverging ideas about the aims of protected areas across societies and about what visitors expect from a protected area. The debate about conservation of landscapes and the use of renewable energies shows that sustainability is interpreted very differently by different stakeholders. In the Alps and in parts of Northern Europe, especially in Iceland (Sæpórsdóttir 2010), power plant development is perceived as reducing the naturalness of places and may affect nature conservation and the development of nature-based tourism. A rising production of renewable energies in the Central European landscapes results in new industrial uses of peripheral and natural landscapes, thus endangering biodiversity and naturalness. Questions arise in the context of current debates about sustainability. In Germany and Switzerland, for instance, the argument for $\mathrm{CO}_{2}$ reduction and therefore the protection of abiotic factors currently seems to be more important than landscape protection. In North America this debate takes on a different turn where the conservation of landscapes and therefore biotic factors is considered more important than their use in terms of renewable energies. The geographical situation and the historic role of protected areas seem to be a major reason for these differences. This results in stricter conservation in the many national parks in America and Scandinavia, whereas in Central Europe natural parks are seen by society as particularly appropriate for renewable energy production. Protected areas in mountain regions are especially affected by new hydroelectric power plants, which are important contributors to the production of renewable energies but at the same time reduce the naturalness of places and diminish landscape and biodiversity protection goals of protected areas in these sensitive mountain regions.

As indicated before, remoteness and population density play a major role in protected area categories, as building new roads and upgrading the accessibility of peripheral regions can lead to more intensive use of these areas. Mountain regions show a mosaic of different accessibilities as the topography leads to very different accessibility situations within a region. This point has to be better reflected, as improving accessibility to protected areas in terms of travel time can make them more vulnerable. An example of a hiking destination in the Caucasus in Georgia shows how new roads in formerly very peripheral regions can weaken the sustainable development of nature-based tourism; as these new roads may lead to new business models (largely owned by external interests) in the region which strongly compete with the guesthouses owned by the local population (Voll et al. 2011; Voll 2012).
These regional natural contexts and the regional social contexts greatly influence the existence of different categories of protected areas. To strengthen the different types of protected areas, also for future developments, more research needs to be undertaken on the relations within these different categories and their systemic governance (including visitor management), the needs, segments and acceptance of tourists, the acceptance of the local population, and the mutual impacts within different political, cultural and ethical contexts.

\section{Visitors in protected areas}

Visitor management in the context of changing demands, values and expectations of tourists (and of the public), the affected population and other stakeholders has increasingly become a new challenge for the management of protected areas. In general, visitors have traditionally been understood as customers, while the literature calls for a visitor-management partnership, where tourists are seen as partners in designing joint services (e. g. Fuchs 2004; Michel 2001). More recent trends in adopting such an understanding can be observed, for example with Parks Canada who implemented a new approach for visitor management: "Instead of viewing the issue as a dichotomy of people versus parks, a cohesive management approach integrates three elements. From here the Agency can achieve its expressed objective of ensuring that Parks Canada programs are representative of and relevant to Canadians," (Jager et al. 2006: 19).

Questions arise, such as what do park visitors these days expect of infrastructure, of the level of protection, of park categories, and (how) do they differ from tourists visiting unprotected destinations? How can the visitor become integrated as a partner in meeting the complex and overlapping objectives of protected areas for ecological preservation, social well-being, cultural integration, but also become integrated in an economic business model, dependent on the willingness-to-pay of visitors. In meeting the needs of a worldwide increase in tourism to protected areas, protected area managers must increasingly pay attention to the type and quality of visitor experience offered and at the same time must protect the ecological integrity of the park (Priskin \& McCool 2006).

Respecting the needs of park visitors is important for funding and acceptance in society as well as for a successful park management, especially as "domestic and international funding for protected areas development has been declining since the 1990s. The global financial crisis that started in 2007 has resulted in increasing public debt and austerity measures in even the more developed countries, with forecasted adverse impacts on protected areas staffing and operations," (McCool et al. 2012: 98-99). In addition to the financial aspects of staffing and operating protected areas, the aspect of cultural change in society and changing visitor needs seems to play a more important role in the demand of nature-based tourism in protected areas. For example, 
visits to Canadian national parks dropped by 3\% from 2001 to 2005 while the overall Canadian population grew by almost $4 \%$ and visiting historical and cultural attractions is one of the fastest growing niche tourism markets (Jager et al. 2006). It is therefore clear that a greater appreciation of tourists' characteristics must underpin any attempt at developing a park's tourism potential (Cochrane 2006). Cochrane (2006) therefore developed a typology of national and international protected area visitors on demographic and behavioural characteristics and / or preferences for facilities and experiences. More information on the acceptance of parks by tourists and the needs of tourists is essential for successfully managing and marketing protected areas, since the greatest challenge related to the visitor experience in protected areas is linked to the management of expectations: "Visitors to protected areas have expectations about what they will see and the level of infrastructures, such as the trails and information facilities, that often have no link to reality. Visitors tend to develop the same expectations about the quality of services available, particularly in relation to education and viewing opportunities no matter which protected area they visit, from a national park in the US to a small protected area in a mountain region in Asia. In the visitors' imagination a protected area is one type of recreation product," (Carbone 2006: 56). To integrate these quality expectations of tourists in the management of a distinct protected area with particular regional settings is a difficult challenge where research has to support protected area management: "While the science of identifying what visitors seek has strong conceptual foundations, the art of managing these opportunities is less well developed. One of the challenges for the future is for closer collaboration involving social scientists and protected area managers," (Priskin \& McCool 2006: 9). For instance, Luthe et al. (2012) did a behavioural study in the Swiss National Park on expectations, willingness-to-pay and behaviour of protected area visitors. Tourists are visiting the SNP mainly out of their interest in nature, while specifically considering social and ecological aspects both in holiday and in daily life behaviour. About $75 \%$ of SNP visitors in this study have a higher willingness-to-pay for sustainable tourism services, in accordance with their generally higher social and ecological awareness and behaviour during holidays and at home. This so-called green tourist, of above average age and education, is visiting the SNP more frequently and staying longer than tourists without this level of integrated sustainability demand and behaviour. Visitors are willing to pay more for sustainable service provision, such as a visit to a protected area, but there remains a need for communicating the concept and implications of sustainable development in protected areas better.

\section{Acceptance and participation of the local population}

In addition to integrating the needs and expectations of tourists in the form of a partnership, there should be a similar focus on the needs and expectations of the local population. Especially in protected areas with a strict conservation mandate, the regional development possibilities can hardly be fully developed without integrating the population in the tourism sector (Forster \& Siegrist 2009). In protected areas with a stronger orientation towards sustainable development, the local population has to be integrated in use and protection strategies. In realizing new protected areas there still exist fears of the local population that the economy could be negatively affected, especially in Europe (Mose \& Weixlbaumer 2003). Therefore Weixlbaumer (2009) refers to two processes where integration is a main success factor for a protected area: the participation of the local population in the management even after a protected area has been established, and at the same time a region-based governance model independent of community politics. This argument is very important in mountainous regions with a long tradition of agriculture and intact cultural landscapes, where extensive farming provides important ecosystem services. Here protected areas have to be managed by integrating the needs of the local population to strengthen the systemic interactions between adapted sustainable use and protection. Forster \& Siegrist (2009), for instance, name the integration of the local tourism industry and the participation of other stakeholders from agriculture, forestry, nature, landscape and local culture as being critical for the success of a protected area. Therefore the development of new touristic options should include the ideas and needs of the local population (Forster \& Siegrist 2009).

Especially in Central Europe the research on local acceptance of protected areas is a relatively new research field, as the foundation of most national parks and other protected areas in Central Europe only started in recent decades (Mose 2009; Job 1996). This shows that more research has to be undertaken to integrate the needs of the local population into protected area governance.

\section{Governance of partnerships}

The interaction between the needs of tourists and the local population, and the categories of protected areas is more or less determined by the status and regulations of the particular protection category. But there is room for progress by better involving the visitors, the local population and other stakeholders in the management of a protected area within their mandate, organized and facilitated by a systemic governance approach. The needs and expectations of visitors and the local population must be aligned with management standards of protected areas, such as limits of acceptable change, visitor impact management or the visitor activity management process. For example, in Finland the protected area authority of Metsähallitus Natural Heritage Services applied the concept of Limits of Acceptable Change, and at the same time created two progressive 
quality programmes in tourism: Green Destination Quality Net (Green DQN ${ }^{\mathrm{TM}}$ ) and Green Destination Management Net $\left(\right.$ Green $\left.\mathrm{DMN}^{\circledR}\right)$, which effectively bring together local actors from the tourism industry and the nature conservation field to promote sustainable tourism (Tapaninen 2010).

The state-of-the-art in visitor experience management concentrates on helping managers to make decisions in management frameworks as Recreation Opportunity Spectrum or Tourism Opportunity Spectrum or Limits of Acceptable Change (McCool 2006). Implementing successful management requires first a regular monitoring of visitor experiences and a careful interpretation of the resulting data, which must be set against specific management and performance indicators and objectives. The findings should be then integrated with other strategic site planning information (Cessford \& $\mathrm{Mu}$ har 2003; Bushell \& Griffin 2006). "Routine monitoring of such things as visitor characteristics, expectations, satisfaction and experiences can contribute to this understanding. Management decisions can then be based on tangible information, not rough judgment," (Bushell \& Griffin 2006: 31). Ideally this information should be collected in a consistent way over time, comparable with other sites and service providers so that benchmarking is possible. It needs to be easily and efficiently collected, and readily and conveniently analysed so that the data is current and reliable, with clear implications for planning and management; and physically and intellectually accessible to all parks agency staff whose management roles could be enhanced by this knowledge about visitors (Bushell \& Griffin 2006). Globally there is a need for integrating these data with the UN List of Protected Areas (Sheppard 2006).

A contemporary visitor experience management would also benefit society: "These benefits may involve reduced family divisiveness, greater worker productivity, increased personal incomes or reduced crime. Benefits from experiencing a bigh quality opportunity might include additional support for a protected area, increased labour income in the local area or an accelerating interest in conservation," (McCool 2006: 4-5). But even today only one quarter of existing protected areas are managed with a high degree of effectiveness (McCool et al. 2012). There are many actors involved in managing tourism in protected areas: local businesses, community and destination marketing, organizations promoting the protected area, planners, architects, engineers and construction workers, scientists and management, which holds the legal responsibility to protect an area's natural heritage (McCool et al. 2012). As Siegrist (2004) among others shows, nature park protagonists and tourist protagonists in nature park tourism in the Alps are suspicious of each other's protection aims. Therefore governance plays a key role, since public interests can be identified, debated and legislated upon via governance processes $(\mathrm{McCool}$ et al. 2012). In addition to integrating the stakeholders in governance processes of protected areas, it could be especially promising to include the visitors in the governance as well in order to manage protected areas according to more adjusted particular needs of visitors in each regional context, thus developing a partnership with tourists (Luthe et al. 2012).

Participatory and multi-level, scale-adapted governance are current responses to the missing effectiveness of environmental policy in Europe and other modern democracies (Newig \& Fritsch 2008). Dearden \& Bennett (2005) found that the management of IUCN protected area categories I-III has become more participatory and that the developing countries have made more progress than the developed ones in ensuring decentralized and participative protected area management. But it is important to consider, that " $[\ldots]$ improved governance can follow multiple pathways. The challenge is to understand the particular context of the protected area systems, globally, nationally, and locally and the various pathways and their advantages and disadvantages. Every situation is unique yet has commonalities that can be better understood through a structured series of case studies at the national and regional levels," (Dearden \& Benett 2005: 98-99). In terms of protected area management and governance, Eagles (2009: 244) compared different protected area management models and governance criteria: “[...] according to standard governance criteria, the combination of government ownership of the resources and non-profit management comes close to the ideals of good governance." But this management concept is often related to a particular financial configuration, "In wealtby localities, with a public that accepts the principle of paying higher taxes in order to gain equity in public services, the national park model prevails. All of Scandinavia fits into this situation. Conversely, in countries where the ability of government to use tax income for conservation is restricted, a parastatal model or the public for-profit model predominates. Most of Africa fits into this situation. This indicates that financial efficiency may be a pivotal criterion, one that underlies all the others. Unless one has financial efficiency, the fulfilment of the other criteria is problematic," (Eagles 2009: 243). When implementing governance structures in national parks it is vital to establish them on the two overarching, interrelated and well recognized goals of conserving natural and cultural resources and providing education and recreation services (Eagles \& McCool 2002). Implementing governance structures in protected areas with a stronger objective on sustainable development, such as IUCN category $\mathrm{V}$ and VI, can bring a wider range of decision making but should respect the fundamental idea of protection in a specific way to avoid some protected areas becoming protected areas for an industrial production of energy, tourism or agriculture.

\section{Synthesis and aspects for future research}

The discussed challenges and opportunities in protected area management and recreation tourism described within the framework of Figure 1 indicate the need for further research that should focus on systemic governance of protected areas embedded in society. 
In the first paragraph we placed protected areas in a systemic context of complex socio-ecological-economic interrelations. Recent developments, like the proposal for expanded renewable energy production in protected areas, add further layers of complexity which need to be considered more in future research on protected areas.

The category and the geographical situation (population density, accessibility) of a protected area play an important role in this context (see paragraph Evolving categories of protected areas). A promising line of research would be to analyse how findings from different cultural, regional and geographical contexts could be implemented better in a systemic governance model in which the visitor and the local population are actively involved in the form of a partnership but at the same time respect the overall goals of the particular protected area category. Especially in mountain regions with a long tradition of agriculture and intact cultural landscapes, where extensive farming provides important ecosystem services and the landscape character is defined by an adapted family farming system, protected areas have to address the interrelations between protection, agricultural use and tourism.

In paragraph Visitors in protected areas we outlined the importance of visitor integration into governance structures. As recent trends in outdoor recreation in the United States and worldwide show, public interest in nature-based recreation and appreciation of natural areas continues to grow. "Participation in most outdoor activities has increased significantly since 1960, with activities such as camping, bicycling, canoeing and skiing increasing as much as tenfold during this time," (Christopher et al. 2009: 1).

More research has to be undertaken on expectations of protected area visitors in different regions, societies and cultures, and how these expectations can be met by involving the visitor as a partner in governance and management. A first step would be to find out more about visitor needs and characteristics in different cultural and ethical contexts through case studies of protected areas in North America, Europe (Scandinavia, Central and Eastern Europe), Africa, Oceania and Asia. Such insights open new opportunities for governing protected areas, a transition from purely accepting visitors to a real partnership, if the relation of the management with visitors is increasingly understood as a joint partnership for sustaining a park in an economic context as well. So-called green tourists, willing to pay more for ecological and social sustainable services and products, both on their holidays and in their daily life, could positively influence the sustainability of protected area governance (Luthe et al. 2012). Besides the changing understanding of visitor expectations, a new interpretation of the demand and the willingness-to-pay for sustainable tourism in protected areas is needed in a multicultural context and in various political and value-ethical surroundings, reflecting the different categories of protection.
Consequently, the local population has to be better involved as well (see paragraph Acceptance and participation of the local population) while respecting the aims of protected area categories within their mandate at regional / national level. In mountain regions it is important to analyse both the expectations of visitors and local stakeholders in a particular geographical setting. This becomes even more important with proposed renewable energy production in some protected area categories in certain geographical regions. Do stakeholders prefer renewable regional energy production which leads to new power plant infrastructure or do they prefer adventure tourism like rafting and naturebased tourism based on ecological integrity in a protected area? Do visitors want to experience wilderness and strict sanctuaries within a protected area, or do they prefer a cultural landscape provided by family farming, which preserves historically and culturally important landscape elements and provides high-quality local products at the same time? Conflicts like these have increased as new categories of protected areas have been implemented, value ethics and demands of visitors and the local population have evolved, and changes in energy politics have led to further pressure. Therefore it is fundamental to understand opinions and needs of stakeholders of a specific protected area, in particular in sensitive mountain regions, to adequately integrate them in governing protected areas.

The integration of visitors and local communities into the management of protected areas is vital for a future governance model of protected areas, adopting the changing demand of politics, population and visitors. A better integration of all stakeholders is essential as most protected areas are funded with public money, while even privately funded parks need to integrate society in the management of the commons. In publicly funded protected areas this integration will be an important argument for the society of a country to provide future financial support. Protected areas can then better integrate differing needs and valuations of ecosystem services in specific regional, geographical and cultural settings.

The new protected area categories V and VI allow for enhanced management possibilities, while even the classic categories I to IV require new management methods and governance (see paragraph Governance of partnerships). Governance structures in protected areas with a stronger focus on sustainable development open up a wider range of decision-making processes and aims; more research has to be undertaken on governance and management in these categories, while respecting the fundamental idea of protection in a contemporary way. The definition of contemporary in this context needs to arise from such future research.

The discussed socioeconomic-ecological elements of protected area governance are interrelated in a complex way, and the goal of developing a contemporary governance model, where population and visitors are integrated in a strategic partnership, calls for a sys- 
temic transdisciplinary research programme, identifying systemic leverage points for intervention, mapping dynamics of developments in a geographical context, and integrating cultural and ethical differences while embracing their complexity. Emphasizing practical relevance, research in the systemic governance that integrates quantitative (natural) with qualitative (social) sciences data can lead to a better understanding of how protected areas should be managed in a sustainable way.

\section{References}

Bishop, K., N. Dudley, A. Phillips \& S. Stolton 2004. Speaking a Common Language: Uses and Performance of the IUCN System of Management Categories for Protected Areas. Cardiff, UK: Cardiff University. The World Conservation Union \& World Conservation Monitoring Centre.

Bushell, R. \& T. Griffin 2006. Monitoring visitor experiences in protected areas. Parks. 16 (2): 25-33.

Carbone, G. 2006. Perspectives of the tourism industry on the elements affecting visitor satisfaction in protected areas. Parks 16 (2): 53-57.

Cessford, G. \& A. Muhar 2003. Monitoring Options for Visitor Numbers in National Parks and Natural Areas. Journal for Nature Conservation 11: 240-250.

Christopher, A., C.A. Monz, D.N. Cole, Y.F. Leung \& J.L. Marion 2009. Sustaining Visitor Use in Protected Areas: Future Opportunities in Recreation Ecology Research Based on the USA Experience 2009. Environmental Management. DOI 10.1007/s00267-009-9406-5.

Cochrane, J. 2006. A typology of tourists to protected areas. Parks 16 (2): 10-17.

Dearden, P. \& M. Bennett 2005. Trends in Global Protected Area Governance 1992-2002. Environmental Management 36 (1): 89-100.

Eagles, P.F.J. 2009. Governance of recreation and tourism partnerships in parks and protected areas. Journal of Sustainable Tourism 17 (2): 231-248.

Eagles, P.F.J. \& S.F. McCool 2002. Tourism in National Parks and Protected Areas. Planning and Management. New York.

Forster, S. \& D. Siegrist 2009. Erfolgsfaktoren für den Tourismus in Pärken und UNESCO-Gebieten. In: Siegrist, D. \& M. Stremlow (eds.), Landschaft Erlebnis Reisen. Naturnaber Tourismus in Pärken und UNESCOGebieten: 107-199. Zürich.

Fuchs, M. 2004. Strategy Development in Tourism Destinations: A Data Envelopment Analysis Approach. Poznan Economics Review 4 (1): 52-73.

IUCN 1994. Guidelines for Protected Areas Management Categories. Gland, Switzerland.

Jager, E., C. Sheedy, F. Gertsch, T. Phillips \& G. Danchuk 2006. Managing for visitor experiences in Canada's national heritage places. Parks 16 (2): 18-33.

Jentoft, S., van Son, T.C. \& M. Bjorkan 2007. Marine Protected Areas: A Governance System Analysis. Human Ecology 36: 611-622.
Job, H. 1996. Großschutzgebiete und ihre Akzeptanz bei Einheimischen - Das Beispiel der Nationalparke im Harz. Geographische Rundschau 48 (3): 159-165.

Locke, H. \& P. Dearden 2005. Rethinking protected area categories and the new paradigm. Environmental Conservation 32 (1): 1-10.

Lockwood, M. 2011. Good governance for terrestrial protected areas: A framework, principles and performance outcomes. Journal of Environmental Management 91 (3): 754-766.

Luthe, T., B. Stangl, F. Joos, S. Nabitz \& P. Boksberger 2012. Green Tourist. Eine Studie zu Bewusstsein und Verhalten von Gästen des Schweizerischen Nationalparks bezüglich Nachhaltigkeit im Urlaub und im Alltag. Bericht Nr. 001812 der ITF Forschungsberichte / ITF Working Papers. Chur.

McCool, S., Y.C. Hsu, S.B. Rocha, A.D. Sæpórsdóttir, L. Gardner \& W. Freimund 2012. Building the capability to manage tourism as support for the Aichi Target. Parks 18 (2): 92-106.

McCool, S. 2006. Managing for visitor experiences in protected areas: promising opportunities and fundamental challenges. Parks 16 (2): 3-9.

McDowell, I. 2010. Measures of self-perceived well-being. Journal of Psychosomatic Research 69: 69-79.

Michel, J. 2001. Erlebnis Berg. Qualitätsanforderungen an Luftseilbahnen und ibre Dienstleistungen. Dissertation at the University of Berne. Institute for Leisure and Tourism (FIF). Berner Studien zu Freizeit und Tourismus. Band 39.

Mose, I. 2009. Akzeptanz, Einstellung und Image als Einflussgrößen von Großschutzgebieten. Einige theoretische und methodische Vorüberlegungen. In: Mose, I. (ed.), Wabrnehmung und Akzeptanz von Großschutzgebieten. Wahrnehmungsgeographische Studien Band 25.

Mose, I. \& N. Weixlbaumer 2003. Großschutzgebiete als Motoren einer nachhaltigen Regionalentwicklung? Erfahrungen mit ausgewählten Schutzgebieten in Europa. In: Hammer, T. (ed.), Großschutzgebiete - Instrumente nachbaltiger Entwicklung: 35-96. München.

Newig, J. \& O. Fritsch 2008. Environmental governance: Participatory, multi-level - and effective? UFZ Diskussionspapiere No. 15/2008.

Phillips, A. 2003. A modern paradigm. World Conservation Bulletin 2: 6-7.

Phillips, A. 2002. IUCN Category V Protected Areas Guidelines - Protected Landscapes / Seascapes. Cambridge, UK \& Gland, Switzerland: IUCN.

Priskin, J. \& S. McCool 2006. The Visitor Experience Challenge. Parks 16 (2): 3-9.

Sæpórsdóttir, A.D. 2010. Tourism struggling as the wilderness is developed. Scandinavian Journal of Hospitality and Tourism 10 (3): 334-357.

Saarinen, J. 2007. Protected areas and regional development issues in northern peripheries: nature protection, traditional economies and tourism in the Urho Kekkonen National Park, Finland. In: Mose I. (ed.), 
Protected areas and regional development in Europe. Towards a new model for the 21, Century: 199-211. Ashgate, Aldershot.

Scholz, R. 2011. Environmantal Literacy in Science and Society. From Knowledge to Decisions.

Sheppard, D. 2006. The New Paradigm for Protected Areas: Implications for Managing Visitors in Protected Areas. In: Siegrist, D., C. Clivaz, M. Hunziker \& S. Iten (eds.), Exploring the Nature of Management. Proceedings of the Third International Conference on Monitoring and Management of Visitor Flows in Recreational and Protected Areas. University of Applied Sciences Rapperswill, Switzerland September 2006: 33-45.

Siegrist, D. 2004. Sustainable tourism and large protected areas - analysis models and success criteria of a sustainable tourism management using the example of the Alps. In: Sievänen, T., J. Erkkonen, J. Jokimäki, J. Saarinen, S. Tuulentie \& E. Virtanen (eds.), Policies, methods and tools for visitor management - proceedings of the second International Conference on Monitoring and Management of Visitor Flows in Recreational and Protected Areas, June 16-20, 2004, Rovaniemi, Finland: 311-317.

Tapaninen, M. 2010. Promotion of sustainable tourism in Finland national parks. In: Hsu, Y.C. (ed.), Proceedings of the Conference on "Vision and strategy for world's national park" and "Issues confronting the management of the world's national park": 65-78.

UN Millenium Ecosystem Assessment 2005. Ecosystems and Human Well-being. Washington, D.C.

Voll, F., N. Eichholz \& V. Riedmann 2010. Nachhaltiger Tourismus in Georgien. Aktuelle Tourismusentwicklungen im Kaukasus am Beispiel Swanetiens. Natur und Mensch Jahresmitteilungen 2010: 47-60.

Voll, F. 2012. Die Bedeutung des Faktors „Erreichbarkeit" für den Alpenraum. Erarbeitung eines alpenweiten Modells der Erreichbarkeit von Metropolen und Regionalzentren vor dem Hintergrund aktueller
Diskussionen um Regionsentwicklung in Abhängigkeit von räumlicher Lage. Available at: http://www. opus.ub.uni-erlangen.de/opus/volltexte/2012/3417/

Weixlbaumer, N. 2009. Schutzgebietslandschaften als Möglichkeitsräume für einen naturnahen Tourismus. In: Siegrist, D. \& M. Stremlow (eds.), Landschaft Erlebnis Reisen. Naturnaher Tourismus in Pärken und UNESCO Gebieten: 191-203. Zürich.

\section{Authors}

\section{Frieder Voll}

is research fellow at the Institute for Tourism and Leisure at the University of Applied Sciences HTW Chur. After his doctoral research on the importance of accessibility and infrastructures for regional development in the Alps, he now applies these results to tourism development in nature-based tourism and protected areas in the Alps and in mountain regions worldwide. Contact: frieder.voll@htwchur.ch

\section{Tobias Luthe}

is Professor for Sustainability Science and Head of Research at the Institute for Tourism and Leisure at the University of Applied Sciences HTW Chur. With a background in both the natural and the social sciences, his major research interests center on the interaction of humans and the environment in a systems understanding, applying a trans- and mulitdisciplinary approach to analysing interrelations within socioeconomic-ecological systems. Contact: tobias.luthe@ htwchur.ch

Institute for Tourism and Leisure, University of Applied Sciences HTW Chur, Comercialstrasse 22, 7000 Chur, Switzerland. 